\title{
Food and nutrient intakes of 9-month-old infants in Adelaide, Australia
}

\author{
Jennifer A Conn ${ }^{1}$, Michael J Davies², Ruth B Walker ${ }^{3}$ and Vivienne M Moore ${ }^{1, *}$ \\ ${ }^{1}$ Discipline of Public Health, University of Adelaide, Adelaide, South Australia 5005, Australia: ${ }^{2}$ Research \\ Centre for Early Origins of Health and Disease, Discipline of Obstetrics \& Gynaecology, University of Adelaide, \\ Adelaide, Australia: ${ }^{3}$ School of Psychology, Flinders University, Adelaide, Australia
}

Submitted 5 September 2008: Accepted 19 February 2009: First published online 30 April 2009

\begin{abstract}
Objective: To describe the food and nutrient intakes of 9-month-old infants.

Design: A survey undertaken as part of a longitudinal study of child growth and development. Infant diet was characterised through a structured interview in which consumption frequency and portion size of foods were obtained. This method was compared with a $4 \mathrm{~d}$ diary and had adequate relative validity.

Setting: Adelaide, Australia.

Subjects: Three hundred and forty-one infants for whom dietary data were plausible according to pre-specified criteria.

Results: At 9 months of age, the median body weights for 161 girls and 180 boys were 8.8 and $9.6 \mathrm{~kg}$, respectively. Differences in intakes between boys and girls largely reflected differences in size. Median daily energy intake was $3541 \mathrm{~kJ}$ and median contributions of protein, fat and carbohydrate to total energy were $13 \%$, $36 \%$ and 50\%. Using published Estimated Average Requirements, Zn intake was inadequate for $<1 \%$ of children not breast-fed at this age while Fe intake was inadequate for $9 \%$. Infants who were still breast-fed $(35 \%)$ had more diversity in the foods that provided additional energy, compared with those not receiving breast milk, and were less likely to consume nutrient-displacing drinks such as juice or cordial. Cow's milk was the main drink for $5 \%$ of infants.

Conclusions: In a group of Australian-born children, an important proportion had weaning diets that were low in Fe. Fat intake of many children was below current recommendations and cow's milk was the main milk source for a small minority.
\end{abstract}

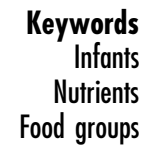

Nutrition during infancy is fundamental to growth and development. Evidence of the long-term health consequences of infant growth patterns continues to accumulate (e.g. references 1-3). Breast-feeding has justifiably been a focus for health promotion interventions and monitoring. Feeding of infants later in the first year has also been the subject of discussion and recommendations (e.g. references 4 and 5), but relatively few population-based studies have documented the composition of weaning diets.

National surveys of infants' diets have been undertaken in the $\mathrm{UK}^{(6)}$ and the $\mathrm{USA}^{(7,8)}$. These and other local studies indicate that weaning diets in high-income countries may be low in Fe, Ca, Zn and vitamin D. A further concern is a possible trend towards relatively low-fat diets for infants, reflecting increased consciousness about fat in the diet more generally ${ }^{(4,9,10)}$.

In Australia, the diets of weaned infants were not included in the national survey of nutrition conducted in 1995 nor in the 2007 national children's nutrition survey, and descriptions of community samples are limited.
Two landmark studies of diet during infancy were undertaken in the $1970 \mathrm{~s}^{(11,12)}$. Those studies provided a wealth of descriptive data, suggested there was a return to breastfeeding, and drew attention to differences in the macronutrient composition of the diet depending on the type of milk or formula consumed. The aim of the present study was to provide current information on the food and nutrient intakes of Australian-born infants at 9 months of age.

\section{Methods}

We surveyed parents with a 9-month-old child as part of a longitudinal study of child growth and development. The children were born to women who participated in a prospective observational study of fetal growth ${ }^{(13)}$. At baseline, women were identified prior to 16 weeks of pregnancy through the antenatal clinic at a public hospital and through the rooms of three privately practising obstetricians. At the hospital, women were approached 
using a random schedule, while at the private practices all eligible women were invited to join the study. The eligibility criteria were being Caucasian, aged at least 18 years, having a single baby who was conceived naturally and being free from insulin-dependent diabetes (which could affect both diet and fetal growth).

The 557 women and children who completed the initial study of fetal growth comprised $96 \%$ of those who joined the study and gave birth to a baby who survived the neonatal period. As intended, the sampling strategy meant that participating women were similar to all women having children in South Australia in 1998-2000 in terms of their age, educational attainment, employment status, household income, relationship status and family size ${ }^{(13)}$. Over $90 \%$ of births in the state are to Caucasian women, with more than $95 \%$ of mothers aged at least 18 years ${ }^{(14)}$.

When each child reached 9 months of age, the primary caregiver was interviewed at home or in one of our offices, as they preferred. Eighty-five per cent of interviews were conducted within two weeks of the target date (not adjusted for prematurity), during 1999-2001. The ethics of the study were approved by the University of Adelaide and written consent was obtained from all participants.

The interview schedule included questions about the child's health and the family's circumstances, as well as feeding practices. The weight of the child, without clothing, was measured to the nearest $10 \mathrm{~g}$ using electronic scales. The supine height of the child was measured in duplicate to the nearest millimetre using a length board.

The dietary intake of the child was ascertained through structured open questions about consumption patterns over the past month, with a food frequency format. The interviewer progressed through the daily meals, drinks and snacks, asking the caregiver to describe the child's favourite and regularly consumed foods. A proforma was followed closely, with food items, consumption frequency and usual portion size recorded on a specially designed form that guided the questions. Where a child was breast-fed, the mother was also asked about the frequency and duration of feeds.

Checklists of commonly eaten foods for each meal (based on separate $24 \mathrm{~h}$ recall data from a convenience sample of 140 mothers) were incorporated as standard prompts. Pictures and labels for complete ranges of manufactured baby foods were assembled for reference. A set of photographs was made to illustrate incremental increases in portion size of a bowl of cereal, with the actual bowl accompanying the photographs during discussion.

Two interviewers conducted all of the dietary assessments. Standard sets of probe questions and prompts were identified from pilot interviews and a protocol for using these was established. Selected interviews were tape-recorded and monitored for adherence to the system of probe questions and prompts. The accuracy of transcription of the conversation into a quantified record was also monitored.
The information recorded on the transcription form was entered into a spreadsheet that linked food items with their nutritional content. Most of the nutritional information was obtained from NUTTAB95 (NUTrient data TABle for use in Australia) ${ }^{(15)}$. Some additional nutritional information was sought from manufacturers of formula milk and infant food products. Product information supplied had been analysed between 1997 and 2000.

The quantity of breast milk consumed was estimated from information on the frequency of feeding only, as descriptions of the duration of feeds were often too variable or vague to be useful in this regard. The volume of breast milk per feed was calculated from data of Dewey et al. ${ }^{(16)}$. Where breast-feeding occurred six or more times daily, the assigned volume was $130 \mathrm{ml}$ per feed, with four or five feeds per day assigned $101 \mathrm{ml}$ per feed and up to three feeds per day assigned $55 \mathrm{ml}$ per feed. The nutritional content of breast milk was obtained from published values ${ }^{(17)}$.

Foods and beverages were classified into sixteen groups, principally following the food codes within NUTTAB. The food groups were cereals, meat and poultry, fish, eggs, dairy (not including cow's milk as a beverage), fruit, vegetables, fats and oils, sugar products, and a miscellaneous group. Beverages were categorised as breast milk, infant formula, cow's milk, water, and 'other'. Infant dinners were kept as a separate group as they were usually combinations of all foods. 'Infant dinners' refers to commercially prepared infant food, marketed as a meal, e.g. 'vegetables, beef and spaghetti' (these were easily identified by mothers using the pictures and labels mentioned above).

We compared the relative validity of our structured interview method of assessing infant diet with $4 \mathrm{~d}$ diet diaries completed by thirty women, contacted through child-care centres, who had a child aged 7 to 13 months (median of 10 months). In principle, the method would be applicable to infants of any age who had commenced eating solid food. We therefore recruited mothers of infants with a wide age range because we wanted to increase the variability of the diets in the relatively small sample. The spreadsheet of nutritional information described above was used to generate estimates of daily intakes of energy, water, nine macronutrients and twelve micronutrients for both sets of dietary details. The median daily energy intake assessed using both the structured interview $(3.7 \mathrm{MJ})$ and the diet diary $(4.0 \mathrm{MJ})$ were higher than the published energy requirements of $3.5 \mathrm{MJ} / \mathrm{d}$ for girls and $3.6 \mathrm{MJ} / \mathrm{d}$ for boys aged 9-12 months, ascertained by the doubly labelled water method ${ }^{(18)}$. However, Spearman's correlation coefficients ranged from 0.57 for energy to 0.97 for riboflavin and the proportion of children assigned to the same or adjacent quartiles of intake on the basis of the two methods ranged from 86 to $100 \%$. Weighted kappa values were above $0 \cdot 4$. Thus, the structured interview performs adequately according to the criteria of Masson et $a l^{(19)}$, although further validation would be desirable. 
To assess the degree of under- and over-reporting in the study, we compared each infant's daily energy intake obtained through the dietary interview with their likely energy requirement. This was calculated using the average energy expenditure of $337 \mathrm{~kJ} / \mathrm{kg}$ for children at 9 months of age, which Davies et al. ${ }^{(20)}$ obtained using the doubly labelled water method. Wells and Davies reported 95\% confidence limits around a total energy expenditure value predicted from body weight as $\pm 46 \%$, compared with the doubly labelled water method, for children from 1.5 to 12 months of age ${ }^{(21)}$. We therefore used this range as our criterion for 'plausible' intakes. Thus we calculated the ratio of reported energy intake to expected energy expenditure for each child, and excluded children for whom this ratio was below 0.56 or above 1.46 for the analyses presented here, as our principal interest was in absolute intakes, which needed to be biologically plausible. (It is possible, for example, that reports of types of food consumed were accurate in excluded individuals, so these data may be useful in other contexts.)

To analyse data collected in the main study, the distributions of nutrients were first inspected for normality. Absolute intakes of polyunsaturated fat, $\mathrm{Na}, \mathrm{Zn}$, vitamins A and $\mathrm{C}$, all sixteen food groups except formula, and nutrient intake per kilogram of body weight for polyunsaturated fat, $\mathrm{Na}, \mathrm{Zn}$ and vitamin $\mathrm{C}$ were not considered to be normally distributed. The intakes for boys and girls, and for breast-fed and non-breast-fed infants, were compared using Student's $t$ test or the Mann-Whitney $U$ test, as appropriate. Comparisons of categorical variables were made using the $\chi^{2}$ test. Due to the large number of comparisons, differences were not considered statistically significant unless $P<0 \cdot 01$. Analyses were undertaken with the SAS statistical software package version 9.2 (SAS Institute, Cary, NC, USA).

Dietary intakes of selected micronutrients were compared with the Nutrient Reference Values for Australia and New Zealand published in $2006^{(22)}$. According to this document, the most appropriate way to estimate the prevalence of inadequate intakes within groups is by comparison with the Estimated Average Requirement (EAR), a value estimated to meet the requirements of half of the healthy individuals in a specific age-sex stratum if consumed on a daily basis. (Recommended Dietary Intakes are derived from EAR, but are no longer considered appropriate to assess adequacy of intakes within groups.) Unfortunately, for infants aged 7-12 months, EAR are available only for $\mathrm{Zn}$ and Fe. For other nutrients an Adequate Intake (AI) is published, where 'usual intake at or above this level has a low probability of inadequacy', but judgements about the adequacy of intakes using AI can be made much less confidently than when EAR are available, since the evidence base for AI is weaker.

\section{Results}

Interviews were completed by 505 parents, mostly women, with a 9-month-old child. For three children the father was the primary caregiver and the principal source of information at this time point. The mothers and their children were part of a longitudinal study in which there were 557 families at the time of birth. Eight of the 557 women (1\%) withdrew prior to their child reaching 9 months of age (one because her child died), thirty-six women $(6 \%)$ were unable to be interviewed on this occasion, and a further eight (1\%) could only provide limited information for reasons such as being interstate. The 505 infants for whom diet was characterised comprised $91 \%$ of the birth cohort.

Among the 505 infants, there were 255 girls and 250 boys. Median weight and length were $8.7 \mathrm{~kg}$ and $71.2 \mathrm{~cm}$, respectively, for girls, and $9.5 \mathrm{~kg}$ and $72.9 \mathrm{~cm}$ for boys. The comparable medians from the US Centers for Disease Control and Prevention 2000 Growth Charts ${ }^{(23)}$, for infants aged 9.5 months, are $8.7 \mathrm{~kg}$ and $70.6 \mathrm{~cm}$ for girls, $9.5 \mathrm{~kg}$ and $72.3 \mathrm{~cm}$ for boys. The median weight for girls exceeded that of the UK 1990 reference group ${ }^{(24,25)}$ by $0 \cdot 1 \mathrm{SD}$, while median height was $0 \cdot 3 \mathrm{SD}$ greater. For boys, the respective medians were $0 \cdot 18 \mathrm{SD}$ and $0.37 \mathrm{SD}$ greater than the UK reference group.

When we applied our criterion for biologically 'plausible' data, based on likely energy requirement, we found that one infant's intake was likely to have been underreported and intakes for 163 infants (32\%) were likely to have been over-reported. As explained previously, overreporting was operationalised as a ratio of reported energy intake to expected energy expenditure greater than $1 \cdot 46$. Half of those excluded for over-reporting had a ratio between 1.46 and $1 \cdot 66$, while twenty-eight (17\%) had a ratio of more than 2 .

There were thus 341 infants with plausible data, comprising $68 \%$ of survey participants. For this subset, median weight and length were $8.8 \mathrm{~kg}$ and $71.5 \mathrm{~cm}$ for girls, and $9 \cdot 6 \mathrm{~kg}$ and $73 \cdot 2 \mathrm{~cm}$ for boys.

The mother's age ranged from 19 to 43 years, with a mean of 31 years. Over $90 \%$ of mothers lived with their partner and nearly two-thirds had more than one child. Twenty-nine per cent of mothers had not completed high school, while $23 \%$ had a university degree. For almost $25 \%$ of households, total income before tax was less than \$AU 31199 per annum. Thus, at least a quarter of the families from whom plausible data were obtained were of low socio-economic status.

Characteristics of the families of children with plausible dietary data and those without are presented in Table 1. Although over-reporting occurred across the socioeconomic spectrum, it was relatively more likely to occur when the mother was disadvantaged. Compared with those with plausible data, mothers of children with implausible data were more likely to be aged less than 30 years, to have left high school early, to have a household income below \$AU 31199 per annum, not to have breastfed and to have introduced solids before 16 weeks. All $\chi^{2}$ tests comparing proportions with the above-mentioned 
Table 1 Characteristics of all mothers and infants surveyed and of the subset with plausible dietary data: 9-month-old infants in Adelaide, Australia, 1999-2001

\begin{tabular}{|c|c|c|c|c|c|c|}
\hline & \multicolumn{2}{|c|}{$\begin{array}{l}\text { All participants } \\
\quad(n 505)\end{array}$} & \multicolumn{2}{|c|}{$\begin{array}{c}\text { Group with plausible infant } \\
\text { dietary data } \\
(n 341)\end{array}$} & \multicolumn{2}{|c|}{$\begin{array}{c}\text { Group with implausible infan } \\
\text { dietary data } \\
(n 164)\end{array}$} \\
\hline & $n$ & $\%$ & $n$ & $\%$ & $n$ & $\%$ \\
\hline \multicolumn{7}{|l|}{ Mother } \\
\hline Age $<30$ years & 213 & $42 \cdot 2$ & 123 & $36 \cdot 1$ & 90 & $54 \cdot 1$ \\
\hline More than one child & 334 & $66 \cdot 1$ & 216 & $63 \cdot 3$ & 118 & $72 \cdot 0$ \\
\hline \multicolumn{7}{|l|}{ Educational attainment } \\
\hline Partial high school & 165 & $32 \cdot 7$ & 98 & $28 \cdot 7$ & 67 & $40 \cdot 9$ \\
\hline Completed high school & 89 & $17 \cdot 6$ & 57 & $16 \cdot 7$ & 32 & $19 \cdot 5$ \\
\hline Technical qualification & 152 & $30 \cdot 1$ & 107 & $31 \cdot 4$ & 45 & $27 \cdot 4$ \\
\hline University degree & 99 & $19 \cdot 6$ & 79 & $23 \cdot 2$ & 20 & $12 \cdot 2$ \\
\hline Currently in paid employment & 165 & $32 \cdot 7$ & 115 & $33 \cdot 7$ & 50 & $30 \cdot \overline{9}$ \\
\hline \multicolumn{7}{|l|}{ Household income (\$AU per annum) } \\
\hline $0-20799$ & 63 & $12 \cdot 5$ & 32 & $9 \cdot 4$ & 31 & $18 \cdot 9$ \\
\hline $20800-31199$ & 92 & $18 \cdot 2$ & 50 & $14 \cdot 7$ & 42 & $25 \cdot 6$ \\
\hline $31200-41599$ & 82 & $16 \cdot 2$ & 57 & $16 \cdot 7$ & 25 & $15 \cdot 2$ \\
\hline $41600-51999$ & 71 & $14 \cdot 1$ & 48 & $14 \cdot 1$ & 23 & $14 \cdot 0$ \\
\hline$\geq 52000$ & 192 & $38 \cdot 0$ & 152 & $44 \cdot 6$ & 40 & $24 \cdot 4$ \\
\hline Not known & 5 & $1 \cdot 0$ & 2 & 0.6 & 3 & $1 \cdot 8$ \\
\hline \multicolumn{7}{|l|}{ Infant } \\
\hline Female & 255 & $50 \cdot 5$ & 161 & $47 \cdot 2$ & 94 & $57 \cdot 3$ \\
\hline Male & 250 & $49 \cdot 5$ & 180 & $52 \cdot 8$ & 70 & $42 \cdot 7$ \\
\hline \multicolumn{7}{|l|}{ Extent of breast-feeding } \\
\hline Never breast-fed & 67 & $13 \cdot 3$ & 41 & $12 \cdot 0$ & 26 & $15 \cdot 9$ \\
\hline Breast-fed at 3 months & 277 & $54 \cdot 9$ & 194 & $56 \cdot 9$ & 83 & $50 \cdot 6$ \\
\hline Breast-fed at 9 months & 157 & $31 \cdot 1$ & 121 & $35 \cdot 5$ & 36 & $22 \cdot 0$ \\
\hline \multirow[t]{2}{*}{ Solids introduced less than 16 weeks } & 162 & $32 \cdot 1$ & 88 & $25 \cdot 8$ & 74 & $45 \cdot 1$ \\
\hline & \multicolumn{2}{|c|}{ Median } & \multicolumn{2}{|c|}{ Median } & \multicolumn{2}{|c|}{ Median } \\
\hline Weight (kg) & \multirow{2}{*}{\multicolumn{2}{|c|}{$\begin{array}{r}9 \cdot 0 \\
72 \cdot 0\end{array}$}} & \multirow{2}{*}{\multicolumn{2}{|c|}{$\begin{array}{r}9.2 \\
72.5\end{array}$}} & \multirow{2}{*}{\multicolumn{2}{|c|}{$\begin{array}{r}8 \cdot 6 \\
71 \cdot 2\end{array}$}} \\
\hline Length (cm) & & & & & & \\
\hline
\end{tabular}

characteristics between the subgroup with plausible data and the subgroup without yielded $P<0 \cdot 04$.

Table 2 presents summary values for estimated nutrient intakes of the 341 infants with plausible data. The median estimated daily energy intake of $3.72 \mathrm{MJ}$ for boys and $3.44 \mathrm{MJ}$ for girls was similar to $3.72 \mathrm{MJ}$ and $3.42 \mathrm{MJ}$, respectively, for a nationally representative sample of nearly 500 British infants ${ }^{(6)}$.

In terms of absolute amounts, boys had greater daily intakes than girls of most nutrients, on average (Table 2). Boys tended to be larger than girls, so this was not surprising. When intakes per kilogram of body weight were compared, there were few gender differences. Intakes of fibre and vitamin $\mathrm{C}$ remained greater for boys than for girls when considered on this basis $(P<0 \cdot 01)$, while the difference in $\mathrm{Mg}$ approached statistical significance at the 0.01 level.

About $35 \%$ of infants received some breast milk at 9 months of age (95\% CI for proportion 30.4, 40.6\%). This compares with $30 \%$ reported by Australian women more generally ${ }^{(26,27)}$. The intakes of nearly all nutrients were significantly lower for infants who were still breastfed compared with infants who were not (Table 3). Only saturated and monounsaturated fats, vitamin A and fibre were not statistically different. Nutrient intakes per kilogram body weight were compared to determine whether differences simply reflected differences in the size of infants in the two groups, as a consequence of gender mix or of the faster growth velocity of formula-fed infants. With the exception of sugar, starch and fat $(P=0 \cdot 016$, $P=0.021$ and $P=0.622)$, the intakes of all nutrients that were significantly lower for breast-fed infants remained so when intakes per kilogram were analysed.

The balance of macronutrients in the diet for infants who were breast-fed and those who were not is summarised in Table 4. Carbohydrates contributed to half of the dietary energy, the majority of this in the form of sugar, with proportions for breast-fed and non-breastfed infants being similar. While dietary energy derived from fat (total, saturated and monounsaturated) was significantly higher for breast-fed infants, overall mean intakes were still lower than the recommended $40 \%$ for this age group. For $12 \%$ of infants, fat contributed less than $30 \%$ of dietary energy. The dietary energy from polyunsaturated fats and protein was significantly higher for infants who were not breast-fed. The only difference between boys and girls was for monounsaturated fats (mean (SD): $12 \cdot 0(2 \cdot 5) \% v \cdot 12 \cdot 7(2 \cdot 8) \%, P=0 \cdot 010)$.

Considering food sources, the majority of 9-month-old infants consumed either breast or formula milk, some type of dairy food, cereal, fruit, vegetables and meat or 
Table 2 Daily nutrient intakes of boys and girls at 9 months of age, Adelaide, Australia, 1999-2001

\begin{tabular}{|c|c|c|c|c|c|c|c|}
\hline & \multicolumn{3}{|c|}{ Boys ( $n 180)$} & \multicolumn{3}{|c|}{ Girls (n 161) } & \multirow[b]{2}{*}{$P$ value } \\
\hline & Mean & SD & Median & Mean & SD & Median & \\
\hline $\begin{array}{l}\text { Total mass }(\mathrm{kg}) \\
\text { Energy }(\mathrm{kJ})\end{array}$ & $3713^{1 \cdot 3}$ & $\begin{array}{l}0.3 \\
656\end{array}$ & ${ }_{3715^{1 \cdot 3}}$ & $3393^{1 \cdot 2}$ & $\begin{array}{c}0 \cdot 2 \\
562\end{array}$ & $3441^{1 \cdot 2}$ & $\begin{array}{l}<0.001 \\
<0.001\end{array}$ \\
\hline Protein (g) & 29 & 8 & 29 & 26 & 8 & 25 & $<0.001$ \\
\hline $\begin{array}{l}\text { Total carbohydrate }(\mathrm{g}) \\
\text { Sugar }(\mathrm{g}) \\
\text { Starch }(\mathrm{g})\end{array}$ & $\begin{array}{r}116 \\
78 \\
38\end{array}$ & $\begin{array}{l}21 \\
19 \\
17\end{array}$ & $\begin{array}{r}117 \\
78 \\
35\end{array}$ & $\begin{array}{r}104 \\
72 \\
32\end{array}$ & $\begin{array}{l}20 \\
16 \\
15\end{array}$ & $\begin{array}{r}103 \\
72 \\
30\end{array}$ & $\begin{array}{r}<0.001 \\
0.002 \\
0.001\end{array}$ \\
\hline $\begin{array}{l}\text { Total fat }(\mathrm{g}) \\
\text { Saturated fat }(\mathrm{g}) \\
\text { Polyunsaturated fat }(\mathrm{g}) \\
\text { Monounsaturated fat }(\mathrm{g})\end{array}$ & $\begin{array}{c}35 \\
16 \\
5 \cdot 2 \\
12\end{array}$ & $\begin{array}{l}8 \\
5 \\
2 \cdot 6 \\
3\end{array}$ & $\begin{array}{c}35 \\
15 \\
5 \cdot 0 \\
12\end{array}$ & $\begin{array}{c}33 \\
15 \\
4 \cdot 9 \\
12\end{array}$ & $\begin{array}{l}7 \\
4 \\
2 \cdot 5 \\
3\end{array}$ & $\begin{array}{c}32 \\
14 \\
4 \cdot 5 \\
11\end{array}$ & $\begin{array}{l}0.022 \\
0.007 \\
0.160 \\
0.294\end{array}$ \\
\hline $\begin{array}{l}\text { Fibre }(\mathrm{g}) \\
\text { Water }(\mathrm{g})\end{array}$ & $1122^{7 \cdot 6}$ & $\begin{array}{l}2 \cdot 5 \\
286\end{array}$ & $1116^{7 \cdot 3}$ & $1014^{6 \cdot 3}$ & $\begin{array}{l}2 \cdot 7 \\
227\end{array}$ & $\begin{array}{l}6 \cdot 1 \\
988\end{array}$ & $\begin{array}{l}<0.001 \\
<0.001\end{array}$ \\
\hline $\begin{array}{l}\mathrm{Na}(\mathrm{mg}) \\
\mathrm{K}(\mathrm{mg}) \\
\mathrm{Ca}(\mathrm{mg}) \\
\mathrm{P}(\mathrm{mg}) \\
\mathrm{Mg}(\mathrm{mg}) \\
\mathrm{Fe}(\mathrm{mg}) \\
\mathrm{Zn}(\mathrm{mg}) \\
\text { Vitamin A }(\mu \mathrm{g}) \\
\text { Thiamin }(\mathrm{mg}) \\
\text { Riboflavin }(\mathrm{mg}) \\
\text { Niacin }(\mathrm{mg}) \\
\text { Vitamin C }(\mathrm{mg})\end{array}$ & $\begin{array}{c}557 \\
1419 \\
677 \\
616 \\
113 \\
10 \cdot 5 \\
6 \cdot 5 \\
851 \\
1 \cdot 0 \\
1 \cdot 4 \\
8 \cdot 5 \\
122\end{array}$ & $\begin{array}{c}315 \\
376 \\
244 \\
206 \\
30 \\
4 \cdot 6 \\
2 \cdot 8 \\
309 \\
0 \cdot 4 \\
0 \cdot 5 \\
2 \cdot 9 \\
63\end{array}$ & $\begin{array}{c}487 \\
1397 \\
630 \\
606 \\
112 \\
9 \cdot 9 \\
5 \cdot 9 \\
818 \\
0 \cdot 9 \\
1 \cdot 3 \\
8 \cdot 1 \\
107\end{array}$ & $\begin{array}{c}474 \\
1247 \\
601 \\
539 \\
98 \\
9 \cdot 3 \\
5 \cdot 7 \\
769 \\
0 \cdot 9 \\
1 \cdot 2 \\
7 \cdot 6 \\
100\end{array}$ & $\begin{array}{c}226 \\
329 \\
183 \\
172 \\
27 \\
4 \cdot 5 \\
2 \cdot 1 \\
250 \\
0 \cdot 4 \\
0 \cdot 5 \\
3 \cdot 3 \\
61\end{array}$ & $\begin{array}{c}414 \\
1205 \\
588 \\
531 \\
97 \\
9 \cdot 7 \\
5 \cdot 5 \\
711 \\
0 \cdot 8 \\
1 \cdot 1 \\
7 \cdot 0 \\
82\end{array}$ & $\begin{array}{r}0.008 \\
<0.001 \\
0.001 \\
<0.001 \\
<0.001 \\
0.018 \\
0.010 \\
0.006 \\
0.152 \\
0.004 \\
0.004 \\
<0.001\end{array}$ \\
\hline
\end{tabular}

Table 3 Daily nutrient intakes of breast-fed and non-breast-fed infants at 9 months of age, Adelaide, Australia, 1999-2001

\begin{tabular}{|c|c|c|c|c|c|c|c|}
\hline & \multicolumn{3}{|c|}{ Breast-fed ( $n$ 121) } & \multicolumn{3}{|c|}{ Not breast-fed ( $n$ 220) } & \multirow[b]{2}{*}{$P$ value } \\
\hline & Mean & SD & Median & Mean & SD & Median & \\
\hline $\begin{array}{l}\text { Total mass }(\mathrm{kg}) \\
\text { Energy }(\mathrm{kJ})\end{array}$ & $3274^{1 \cdot 1}$ & $\begin{array}{c}0 \cdot 2 \\
598\end{array}$ & $3389^{1 \cdot 1}$ & $\begin{array}{l}1 \cdot 3 \\
3720^{-3}\end{array}$ & $\begin{array}{l}0.3 \\
596\end{array}$ & $3709^{1 \cdot 3}$ & $\begin{array}{l}<0.001 \\
<0.001\end{array}$ \\
\hline Protein (g) & 23 & 7 & 23 & 30 & 8 & 30 & $<0.001$ \\
\hline $\begin{array}{l}\text { Total carbohydrate }(\mathrm{g}) \\
\text { Sugar }(\mathrm{g}) \\
\text { Starch }(\mathrm{g})\end{array}$ & $\begin{array}{r}101 \\
69 \\
31\end{array}$ & $\begin{array}{l}19 \\
17 \\
13\end{array}$ & $\begin{array}{r}101 \\
68 \\
30\end{array}$ & $\begin{array}{r}116 \\
78 \\
37\end{array}$ & $\begin{array}{l}21 \\
18 \\
17\end{array}$ & $\begin{array}{r}116 \\
79 \\
34\end{array}$ & $\begin{array}{r}<0.001 \\
<0.001 \\
0.001\end{array}$ \\
\hline $\begin{array}{l}\text { Total fat }(\mathrm{g}) \\
\text { Saturated fat }(\mathrm{g}) \\
\text { Polyunsaturated fat }(\mathrm{g}) \\
\text { Monounsaturated fat }(\mathrm{g})\end{array}$ & $\begin{array}{c}33 \\
15 \\
3 \cdot 2 \\
12\end{array}$ & $\begin{array}{l}8 \\
4 \\
1 \cdot 3 \\
3\end{array}$ & $\begin{array}{c}32 \\
14 \\
2 \cdot 9 \\
11\end{array}$ & $\begin{array}{l}35 \\
16 \\
6 \cdot 1 \\
12\end{array}$ & $\begin{array}{l}7 \\
4 \\
2 \cdot 5 \\
3\end{array}$ & $\begin{array}{c}34 \\
15 \\
5 \cdot 7 \\
12\end{array}$ & $\begin{array}{r}0.010 \\
0.254 \\
<0.001 \\
0.382\end{array}$ \\
\hline $\begin{array}{l}\text { Fibre (g) } \\
\text { Water (g) }\end{array}$ & $944^{7 \cdot 1}$ & $\begin{array}{c}2 \cdot 8 \\
225\end{array}$ & $\begin{array}{l}6 \cdot 9 \\
956\end{array}$ & $\begin{array}{c}6 \cdot 9 \\
1141\end{array}$ & $\begin{array}{c}2 \cdot 6 \\
259\end{array}$ & ${ }^{6 \cdot 8}$ & $\begin{array}{r}0.356 \\
<0.001\end{array}$ \\
\hline $\begin{array}{l}\text { Na }(\mathrm{mg}) \\
\mathrm{K}(\mathrm{mg}) \\
\mathrm{Ca}(\mathrm{mg}) \\
\mathrm{P}(\mathrm{mg}) \\
\mathrm{Mg}(\mathrm{mg}) \\
\mathrm{Fe}(\mathrm{mg}) \\
\mathrm{Zn}(\mathrm{mg}) \\
\text { Vitamin A }(\mu \mathrm{g}) \\
\text { Thiamin }(\mathrm{mg}) \\
\text { Riboflavin }(\mathrm{mg}) \\
\text { Niacin }(\mathrm{mg}) \\
\text { Vitamin C }(\mathrm{mg})\end{array}$ & $\begin{array}{c}453 \\
1212 \\
489 \\
451 \\
91 \\
6 \cdot 3 \\
4 \cdot 7 \\
777 \\
0 \cdot 7 \\
1 \cdot 0 \\
6 \cdot 6 \\
91\end{array}$ & $\begin{array}{c}228 \\
330 \\
147 \\
159 \\
28 \\
3 \cdot 4 \\
1 \cdot 8 \\
319 \\
0 \cdot 4 \\
0 \cdot 4 \\
2 \cdot 6 \\
55\end{array}$ & $\begin{array}{c}414 \\
1167 \\
469 \\
431 \\
92 \\
5 \cdot 8 \\
4 \cdot 3 \\
712 \\
0 \cdot 7 \\
0 \cdot 9 \\
6 \cdot 0 \\
72\end{array}$ & $\begin{array}{c}554 \\
1406 \\
724 \\
651 \\
114 \\
11 \cdot 9 \\
6 \cdot 9 \\
832 \\
1 \cdot 0 \\
1.5 \\
8 \cdot 9 \\
123\end{array}$ & $\begin{array}{c}298 \\
365 \\
209 \\
175 \\
27 \\
3 \cdot 9 \\
2 \cdot 6 \\
264 \\
0 \cdot 4 \\
0.5 \\
3 \cdot 1 \\
64\end{array}$ & $\begin{array}{c}506 \\
1380 \\
705 \\
642 \\
113 \\
11 \cdot 6 \\
6 \cdot 2 \\
781 \\
0 \cdot 9 \\
1 \cdot 4 \\
8 \cdot 4 \\
106\end{array}$ & $\begin{aligned} & 0.001 \\
&< 0.001 \\
&< 0.001 \\
&<0.001 \\
&<0.001 \\
&<0.001 \\
&<0.001 \\
& 0.014 \\
&<0.001 \\
&<0.001 \\
&<0.001 \\
&<0.001\end{aligned}$ \\
\hline
\end{tabular}

poultry. Relatively small proportions of infants were consuming fish and egg dishes. There were few statistical differences in food consumption between boys and girls, and only the daily intake of water remained greater for boys than girls $(P<0 \cdot 01)$ when food consumption per kilogram of body weight was compared.

However, food sources and amounts consumed by breast-fed and non-breast-fed infants differed (Table 5). 
Table 4 Contribution of macronutrients to total energy for breast-fed and non-breast-fed infants at 9 months of age Adelaide, Australia, 1999-2001

\begin{tabular}{|c|c|c|c|c|c|}
\hline \multirow[b]{2}{*}{ Macronutrient } & \multicolumn{2}{|c|}{ Breast-fed $(n 121)$} & \multicolumn{2}{|c|}{ Not breast-fed (n 220) } & \multirow[b]{2}{*}{$P$ value } \\
\hline & Mean & SD & Mean & SD & \\
\hline$\%$ Protein & $11 \cdot 9$ & $2 \cdot 7$ & $13 \cdot 8$ & $2 \cdot 3$ & $<0.001$ \\
\hline $\begin{array}{l}\text { \% Carbohydrate } \\
\% \text { Sugar } \\
\% \text { Starch }\end{array}$ & $\begin{array}{l}49 \cdot 6 \\
33 \cdot 9 \\
15 \cdot 5\end{array}$ & $\begin{array}{l}4 \cdot 9 \\
5 \cdot 5 \\
6 \cdot 1\end{array}$ & $\begin{array}{l}49 \cdot 8 \\
33 \cdot 8 \\
15 \cdot 8\end{array}$ & $\begin{array}{l}4 \cdot 6 \\
6 \cdot 8 \\
6 \cdot 5\end{array}$ & $\begin{array}{l}0.759 \\
0.953 \\
0.621\end{array}$ \\
\hline $\begin{array}{l}\text { \% Fat } \\
\% \text { Saturated fat } \\
\% \text { Polyunsaturated fat } \\
\% \text { Monounsaturated fat }\end{array}$ & $\begin{array}{r}36 \cdot 8 \\
17 \cdot 2 \\
3 \cdot 6 \\
13 \cdot 1\end{array}$ & $\begin{array}{l}6 \cdot 0 \\
3 \cdot 1 \\
1 \cdot 2 \\
2 \cdot 9\end{array}$ & $\begin{array}{r}34 \cdot 9 \\
15 \cdot 7 \\
6 \cdot 1 \\
11 \cdot 9\end{array}$ & $\begin{array}{l}4 \cdot 3 \\
3 \cdot 1 \\
2 \cdot 4 \\
2 \cdot 4\end{array}$ & $\begin{array}{r}0.002 \\
<0.001 \\
<0.001 \\
<0.001\end{array}$ \\
\hline
\end{tabular}

Table 5 Proportion of breast-fed and non-breast-fed infants consuming selected foods at 9 months of age and the mean and median daily intake among consumers, Adelaide, Australia, 1999-2001

\begin{tabular}{|c|c|c|c|c|c|c|c|c|}
\hline & \multicolumn{4}{|c|}{ Breast-fed } & \multicolumn{4}{|c|}{ Not breast-fed } \\
\hline & \multirow[b]{2}{*}{$\%$ Consuming } & \multicolumn{3}{|c|}{ Daily intake (g) } & \multirow[b]{2}{*}{$\%$ Consuming } & \multicolumn{3}{|c|}{ Daily intake (g) } \\
\hline & & Mean & SD & Median & & Mean & SD & Median \\
\hline Breast milk & 100 & 426 & 250 & 404 & 0 & - & - & - \\
\hline Formula & 31 & 231 & 209 & 190 & $92^{* *}$ & $690^{* *}$ & 180 & 700 \\
\hline Cow's milk & 51 & 96 & 116 & 65 & 49 & 160 & 232 & 65 \\
\hline Water & 93 & 125 & 136 & 83 & 95 & 178 & 205 & $119^{*}$ \\
\hline Other drinks & 45 & 34 & 45 & 16 & $62^{*}$ & 51 & 61 & 31 \\
\hline Cereals & 100 & 51 & 42 & 40 & 100 & 50 & 55 & 42 \\
\hline Dairy foods (excl. cow's milk) & 95 & 109 & 87 & 86 & 96 & 119 & 76 & 114 \\
\hline Meat or poultry & 78 & 18 & 24 & 10 & 66 & 22 & 31 & 11 \\
\hline Fish & 42 & 7 & 8 & 3 & $27^{*}$ & 7 & 10 & 3 \\
\hline Eggs & 21 & 8 & 13 & 3 & 20 & 6 & 7 & 3 \\
\hline Fruit & 98 & 108 & 79 & 94 & 92 & 83 & 61 & $72^{*}$ \\
\hline Vegetables & 92 & 98 & 72 & 85 & 89 & 82 & 68 & 68 \\
\hline Infant dinners & 59 & 66 & 59 & 50 & 64 & 102 & 80 & $85^{\star \star}$ \\
\hline Fats and oils & 48 & 3 & 2 & 2 & 54 & 4 & 4 & 3 \\
\hline Sugar and products & 31 & 8 & 16 & 3 & 39 & 5 & 9 & 2 \\
\hline Miscellaneous & 63 & 17 & 32 & 4 & 68 & 14 & 26 & 4 \\
\hline
\end{tabular}

Values were significantly different from those of breast-fed infants: ${ }^{*} P<0.01,{ }^{* *} P<0.001$.

As expected, breast-fed infants were less likely to drink formula, and if they did so, the mean daily intake was comparatively low. Although similar proportions of breast-fed and non-breast-fed infants ate infant dinners, the amounts consumed by the former were significantly lower. Infants who still received breast milk were more likely than their counterparts to eat fish, and had a tendency to be more likely to eat meat or poultry $(P=0.023)$ and fruit $(P=0 \cdot 036)$; those who consumed fruit ate a greater amount. Thus, in terms of the number of different foods eaten, breast-fed infants had more diverse diets. In addition to formula, infants who were not breast-fed at 9 months were more likely to have 'other drinks' (including fruit juice, cordial and soft drinks) and tended to consume a greater amount of these drinks $(P=0 \cdot 014)$. Infants not receiving breast milk at this age also had more water (usually with cordial) than those still breast-fed. These differences were similar when analysed per kilogram of body weight.
For those infants who received some breast milk, on average total milk drinks accounted for $48 \%$ of daily energy intake $(38 \%$ breast milk). The number of breast feeds ranged from just two feeds per week (in an infant for whom breast-feeding ceased during the reference period) to nine feeds per day, with median intake of breast milk of $404 \mathrm{ml}$ (interquartile range $193-505 \mathrm{ml}$ ). The infants who were not breast-fed at this stage obtained, on average, $54 \%$ of daily energy intake from milk drinks. Of note, eighteen of the infants who were not breast-fed were not receiving formula and were being fed predominantly full-cream cow's milk ( $5 \%$ of the sample).

AI reference values for $\mathrm{Na}, \mathrm{K}, \mathrm{Ca}, \mathrm{P}, \mathrm{Mg}$, thiamin, riboflavin, niacin and vitamin $\mathrm{C}(170,700,270,275,75,0 \cdot 3$, $0.4,4$ and $30 \mathrm{mg} / \mathrm{d}$, respectively) were compared with group mean intakes of these micronutrients. For both breast-fed and non-breast-fed infants, group means were greater than the AI, so the prevalence of inadequate intake is likely to be low, although these results must be treated 
with caution because an AI reflects a relative lack of data upon which to make recommendations. For $\mathrm{Zn}$ and Fe, EAR are for this age group are 2.5 and $7 \mathrm{mg} / \mathrm{d}$, respectively (and assume that the proportion absorbed is that for a mixed Western diet, so cannot be applied to breast-fed infants, for whom bioavailability is considerably greater). On this basis, among infants not breast-fed at 9 months of age, very few $(<1 \%)$ were likely to have inadequate $\mathrm{Zn}$ intake but $9 \%$ were likely to have inadequate Fe intake.

\section{Discussion}

We have described the weaning diets of a group of Australian-born children. Our data suggest that an important proportion had low intake of Fe. There was more variety in the foods provided to infants still breastfed at 9 months and infants not being breast-fed were more likely to consume drinks such as juice or cordial, which are relatively poor sources of nutrients. A minority was given cow's milk as the main drink.

These data pertain to a subset of a birth cohort of children. While dietary data were collected for the majority of the cohort, reported intakes for about $30 \%$ of infants did not meet our criterion for plausibility. The extent of misreporting we detected was similar to that identified by researchers who used a $3 \mathrm{~d}$ diary in the Avon Longitudinal Study of Pregnancy and Childhood (ALSPAC) to assess the diets of children at 8 months of age $^{(28)}$, and was not unexpected given the recognised difficulties of quantifying infants' diets ${ }^{(4)}$. Using our prespecified criterion, over-reporting of infant intakes was much more common than under-reporting. A tendency to over-reporting rather under-reporting has been noted by other researchers ${ }^{(29)}$, who have suggested that parents do not wish to be seen to be under-feeding infants. This tendency could also arise from difficulty in distinguishing between food offered to young children and the amount actually consumed ${ }^{(4)}$. Fisher et al. recently published evidence that $24 \mathrm{~h}$ recall data for infants and toddlers (a method routinely used in the USA) overestimated intakes compared with $3 \mathrm{~d}$ weighed records ${ }^{(30)}$.

The mothers and children in the cohort as a whole are broadly representative of the community in which they reside $^{(13)}$. In the present analysis, those excluded on the basis that data were biologically implausible (using a strict criterion) came from all socio-economic backgrounds, but were relatively more likely to be disadvantaged. Thus, in the whole cohort approximately one-third of families were of low socio-economic status, but closer to onequarter of families were of low socio-economic status in the subset with plausible infant dietary data. The under-representation of the poorest families is therefore present, but not extreme. Nevertheless, our data on food and nutrient intakes are likely to reflect a degree of bias towards 'better' nutritional practices. The impact of such bias on various estimates is complicated by the fact that, compared with those not receiving breast milk, infants who were still breast-fed had lower intakes of most nutrients.

The last survey of infant diets in this city was undertaken almost three decades ago ${ }^{(11)}$ and focused on diets of formula-fed infants at 6 and 12 months of age. The distribution of energy intakes for 9-month-old infants not being breast-fed in the present study was similar to that of 12 -month-old infants in the historical study. The proportion of energy derived from fat was similar (34\%), while protein was historically somewhat higher for infants at both 6 and 12 months (15\%, 16\%) and carbohydrate lower (49\%), with the magnitude of these differences matching changes observed in older children between the 1985 and the 1995 National Nutrition Surveys ${ }^{(29)}$.

There are no national data on the diets of Australian infants around weaning, so we compared our dietary profiles with the British national study ${ }^{(6)}$ of children aged 6-12 months undertaken in 1986, in which diet was assessed using an unweighed $7 \mathrm{~d}$ record. The median daily energy intake $(3.52 \mathrm{MJ})$ and macronutrient profile (protein 14\%, carbohydrate 50\%, fat 36\%) of the British infants aged 6-9 months, most of whom were not receiving breast milk, were similar to those of infants in our study who were no longer breast-fed. Despite this overall similarity, in our sample the energy derived from carbohydrate reflected a greater intake of sugar $34 \% v$. $31 \%$ ) and lower intake of starch than in the British study, and there was greater replacement of saturated fat by polyunsaturated fat $(6 \% v, 4 \%)$. Median intakes of $\mathrm{Fe}, \mathrm{Zn}$ and vitamin $\mathrm{C}$ were more than $25 \%$ higher in our sample, and $\mathrm{Na}$ was $30 \%$ lower. Some of these differences are likely to be due to the much lower consumption of cow's milk in our sample, reflecting recommendations made strongly some years after the completion of the British study.

We observed differences between absolute intakes of boys and girls, generally reflecting differences in size. The one exception was consumption of fruit, which was greater for boys than girls even when weight was taken into account. In the British national study ${ }^{(6)}$, intakes of most nutrients were also higher for boys than girls, but there was little difference in the contribution of main food types to total energy.

In our sample, a third of infants were still breast-fed at 9 months of age, similar to national estimates for the same period $^{(26,27)}$. Compared with those receiving breast milk, infants who were not breast-fed at 9 months had higher intakes of almost all nutrients, both in absolute amounts and when considered per kilogram of body weight. It is possible that mothers who still breast-fed their infants reported feeding practices in ways that differed systematically from other mothers. However, the differences in nutrient intakes appeared to be principally due to the type of milk consumed, as the energy derived from sources other than milk drinks was similar (mean of $1 \cdot 7 \mathrm{MJ} / \mathrm{d}$ ). Lower intakes of certain micronutrients by 
breast-fed infants are not necessarily of concern, as there is greater bioavailability of micronutrients such as Fe and $\mathrm{Zn}$ in breast milk (e.g. reference 31).

In past studies of diet in the latter part of infancy, children still receiving breast milk have either been excluded or have represented a small proportion (e.g. reference 6). In the more recent ALSPAC cohort, about a quarter of children whose diets were assessed at 8 months were still breast-fed ${ }^{(28)}$. Our findings are consistent with the lower intakes of many nutrients reported for breastfed compared with non-breast-fed infants in the ALSPAC study. We used a similar method of estimating breast milk intake, based on frequency of feeds. While this approach is fairly crude and does not take into account duration of feeds, changes in milk composition during a feed or during stage of lactation, or other factors that might contribute to variation in breast milk production, it is not clear that it would result in systematic underestimation. Butte's equations ${ }^{(18)}$, based on thirteen studies, indicate that energy requirements of breast-fed infants are lower than formula-fed infants, even when weight and age are taken into account.

It is notable that when comparing sources other than milk, the children who were not breast-fed at 9 months were more likely to consume nutrient-displacing drinks such as juice, soft drink or cordial, while those still breast-fed were provided with a greater variety of foods. Cow's milk was the main drink for $5 \%$ of children in the sample, despite recommendations against this practice for this age group ${ }^{(5,32)}$.

Breast milk contains about $50 \%$ fat, whereas cereal or vegetable-based meals typical of the weaning period are relatively low in fat. Internationally, concerns have been raised about inadequate fat intake in young children following weaning (e.g. reference 33), which could reduce activity (hindering development) and impair growth, although there are limited data on these risks and some disagreement exists. The vulnerability of infants has meant that the proposition of dietary fat restriction during infancy, in order to improve longer-term metabolic health, is generally not supported by bodies responsible for recommendations ${ }^{(34)}$. In our sample, fat contributed, on average, $37 \%$ of dietary energy for children who were still breast-fed and 35\% for children who were not. The Australian National Health and Medical Research Council recommendation ${ }^{(5)}$ is that the weaning diet should comprise about $40 \%$ fat, a level not met by approximately $80 \%$ of this sample.

Additional complexity in the debate about dietary fat has come with recent suggestions that, in young children, fat may be replaced by protein, which could be unhealthy through the increased solute load and bioactivity of amino $\operatorname{acids}^{(35)}$. The data for our sample suggest that sugar, rather than protein, is replacing fat. This pattern of exchange has been documented in older children (e.g. reference 36) and has different implications for health ${ }^{(37)}$. In young children, this could have an impact on nutrient intakes as the nutrient density of sugary foods and drinks is typically low, and it could increase the risk of dental caries.

$\mathrm{Fe}, \mathrm{Ca}$ and $\mathrm{Zn}$ intakes of young children are widely documented concerns. Very low intake of Fe can cause developmental delay, which is thought to represent the extreme of an underlying continuum of adverse effects ${ }^{(4)}$. Among other functions, $\mathrm{Ca}$ is noted for its role in building bones and teeth ${ }^{(4)}$. $\mathrm{Zn}$ is involved in a range of metabolic processes and inadequate intake may limit growth ${ }^{(4)}$. Comparison with AI reference values provides some reassurance that intakes of $\mathrm{Ca}$ were adequate. Comparisons with EAR provide stronger evidence that intakes of $\mathrm{Zn}$ were adequate in almost all children not breast-fed at this age, but almost one in ten children not breast-fed had inadequate intake of $\mathrm{Fe}$. Current recommendations for health workers ${ }^{(5)}$ encourage Fe-fortified cereals as the first solid foods to introduce to infants, later followed by meat. Greater consumption of appropriately prepared meat, fish and wholegrain cereal could improve the intake of Fe.

The infants in this sample had diets that were adequate in many nutrients, but efforts to improve intakes of Fe are needed, as well as continued emphasis on the need to limit cow's milk but not fat. Planned follow-up of these children will be valuable to investigate effects of infant diet on aspects of future health.

\section{Acknowledgements}

Sources of funding: This study was supported by grants from the Dairy Research and Development Corporation of Australia, the Faculty of Health Sciences at the University of Adelaide, and the South Australian Channel 7 Children's Research Foundation. Conflict of interest declaration: The authors have no conflict of interest. Author contributions: J.A.C. and V.M.M. were primary writers of the paper. M.J.D. and R.B.W. contributed to selected sections and commented on drafts. Acknowledgements: We are grateful to the women and children who participated in the Generation 1 Study and also to the partners and other family members who helped to make the study possible. We wish to thank Kendall Smith, Lisa Masters and Deborah Roffe for interviewing women and other data collection; Anthea Page for database programming; Kaye Robinson for data entry; Heather McElroy for contributing to preliminary analyses; and Kristyn Willson and Tom Sullivan for further statistical assistance. The assistance of staff at the Lyell McEwin Health Service, Dr Basil Antonas, Carol Murray, Dr John Svigos, Jane Christiansen, Dr Xen Xenophou, Maryann Baker and other practice staff and of staff at the five hospitals where the children were born was very valuable in establishing the cohort. The encouragement and support of Dr Peter Parodi, Professor Tony Worsley and Professor Jeffrey Robinson is much appreciated. 


\section{References}

1. Fall CHD, Vijayakumar M, Barker DJP, Osmond C \& Duggleby S (1995) Weight in infancy and prevalence of coronary heart disease in adult life. BMJ 310, 17-19.

2. Gunnell DJ, Davey Smith G, Frankel S, Nanchahal K, Braddon FE, Pemberton J \& Peters TJ (1998) Childhood leg length and adult mortality: follow up of the Carnegie (Boyd Orr) Survey of Diet and Health in Pre-war Britain. J Epidemiol Community Health 52, 142-152.

3. Eriksson JG, Forsen T, Tuomilehto J, Osmond C \& Barker JP (2001) Early growth and coronary heart disease in later life: longitudinal study. BMJ 322, 949-953.

4. Department of Health (1994) Weaning and the Weaning Diet. Report of the Working Group on the Weaning Diet of the Committee on Medical Aspects of Food Policy. Report on Health and Social Subjects no. 45. London: HMSO.

5. National Health and Medical Research Council (2003) Dietary Guidelines for Adolescents and Children in Australia - Incorporating the Infant Feeding Guidelines for Health Workers. Catalogue no. 0326111. Canberra: NHMRC.

6. Mills A \& Tyler H (1992) Food and Nutrient Intakes of British Infants Aged 6-12 Months. London: HMSO.

7. Ernst JA, Brady MS \& Rickard KA (1990) Food and nutrient intake of 6- to 12-month-old infants fed formula or cow milk: a summary of four national surveys. J Pediatr 117, S86-S100.

8. Devaney B, Ziegler P, Pac S, Karwe V \& Barr SI (2004) Nutrient intakes of infants and toddlers. J Am Diet Assoc 104, Suppl. 1, S14-S21.

9. Hardy SC \& Kleinman RE (1994) Fat and cholesterol in the diet of infants and young children: implications for growth, development, and long term health. J Pediatr 125, S69-S77.

10. World Health Organization (1998) Complementary Feeding of Young Children in Developing Countries: A Review of Current Scientific Knowledge. Geneva: WHO.

11. Boulton J (1981) Nutrition in childhood and its relationships to early somatic growth, body fat, blood pressure, and physical fitness. Acta Pediatr Scand Suppl 284, 1-85.

12. Hitchcock NE, Gracey M, Gilmour AI \& Owles EN (1986) Nutrition and Growth in Infancy and Early Childhood: $A$ Longitudinal Study from Birth to 5 Years. Basel: Karger.

13. Moore VM, Davies MJ, Willson KJ, Worsley A \& Robinson JS (2004) Dietary composition of pregnant women is related to size of the baby at birth. J Nutr 134, 1820-1826.

14. Chan A, Scott J, Nguyen A-M \& Keane R (2000) Pregnancy Outcome in South Australia 1999. Adelaide: Pregnancy Outcome Unit, Epidemiology Branch, Department of Human Services.

15. Lewis J \& Holt R (1992) NUTTAB91-92. Canberra: National Food Authority, Commonwealth Government of Australia.

16. Dewey KG, Finley DA \& Lonnerdal B (1984) Breast milk volume and composition during late lactation (7-20 months). J Pediatr Gastroenterol Nutr 3, 713-720.

17. Department of Health and Social Security (1977) The Composition of Mature Human Milk. Report of the Working Party on the Composition of Foods for Infants and Young Children. Report on Health and Social Subjects no. 12. London: HMSO.

18. Butte NF (1996) Energy requirements of infants. Eur J Clin Nutr 50, Suppl. 1, S24-S36.

19. Masson LF, McNeill LF, McNeill G, Tomany JO, Simpson JA, Peace HS, Wei L, Grubb DA \& Bolton-Smith C (2003) Statistical approaches for assessing the relative validity of a food-frequency questionnaire: use of correlation coefficients and the kappa statistic. Public Health Nutr $\mathbf{6}$, 313-321.

20. Davies PSW, Coward WA, Gregory J, White A \& Mills A (1994) Total energy expenditure and energy intake in the pre-school child. Br J Nutr 72, 13-20.

21. Wells JCK \& Davies PSW (1999) Can body size predict infant energy requirements? Arch Dis Child 81, 429-430.

22. National Health and Medical Research Council (2006) Nutrient Reference Values for Australia and New Zealand including Recommended Dietary Intakes. Canberra: NHMRC.

23. Ogden CL, Kuczmarski RJ, Flegal KM, Mei Z, Guo S, Wei R, Grummer-Strawn LM, Curtin LR, Roche AF \& Johnson CL (2002) Centers for Disease Control and Prevention 2000 Growth Charts for the United States: improvements to the 1977 National Center for Health Statistics version. Pediatrics 109, 45-60.

24. Freeman JV, Cole TJ, Chinn S, Jones PRM, White EM \& Preece MA (1995) Cross sectional stature and weight reference curves for the UK, 1990. Arch Dis Child 73, $17-24$.

25. Preece M, Freeman J \& Cole T (1995) Sex difference in weight in infancy: published centile charts have been updated. BMJ 313, 1486.

26. Australian Bureau of Statistics (2003) Breastfeeding in Australia. Catalogue no. 4810.0.55.01. Canberra: Australian Government Publishing Service.

27. Donath SM \& Amir LH (2005) Breastfeeding and the introduction of solids in Australian infants: data from the 2001 National Health Survey. Aust N Z J Public Health 29, 171-175.

28. Noble S, Emmett P \& the ALSPAC Study Team (2001) Food and nutrient intake in a cohort of 8-month-old infants in the South West of England in 1993. Eur J Clin Nutr 55, 698-707.

29. Cook T, Rutishauser I \& Seelig M (2002) Comparable Data on Food and Nutrient Intake and Physical Measurements from the 1983, 1985 and 1995 National Nutrition Surveys. Brisbane: Australian Food and Nutrition Monitoring Unit, University of Queensland.

30. Fisher JO, Butte NF, Mendoza PM, Wilson TA, Hodges EA, Reidy KC \& Deming D (2008) Overestimation of infant and toddler energy intake by 24-h recall compared with weighed food records. Am J Clin Nutr 88, 407-415.

31. Bosscher D, Van Caillie-Bertrand M, Robberecht H, Van Dyck K, Van Cauwenbergh R \& Deelstra H (2001) In vitro availability of calcium, iron, and zinc from first-age infant formulae and human milk. J Pediatr Gastroenterol Nutr 32, $54-58$.

32. National Health and Medical Research Council (1995) Dietary Guidelines for Children and Adolescents. Catalogue no. 9557075. Canberra: NHMRC.

33. Koletzko B (1999) Response to and range of acceptable fat intakes in infants and children. Eur J Clin Nutr 53, Suppl. 1, S78-S83.

34. Milner JA \& Allison RG (1999) The role of dietary fat in child nutrition and development: summary of an ASNS workshop. J Nutr 129, 2094-2105.

35. Michaelsen KF (2000) Are there negative effects of an excessive protein intake? Pediatrics 106, 1293.

36. Nicklas TA, Webber LS, Koschak M \& Berenson GS (1992) Nutrient adequacy of low fat intakes for children: the Bogalusa Heart Study. Pediatrics 89, 221-228.

37. Department of Health (1989) Panel on Dietary Sugars. Dietary Sugars and Human Disease. Report on Health and Social Subjects no. 37. London: HMSO. 